\title{
The 1856 Djijelli (Algeria) earthquake and tsunami: source parameters and implications for tsunami hazard in the Balearic Islands
}

\author{
J. Roger and H. Hébert \\ Département Analyse, Surveillance, Environnement, Commissariat à l'Energie Atomique, 91297 Arpajon Cedex, France
}

Received: 18 February 2008 - Revised: 3 June 2008 - Accepted: 10 June 2008 - Published: 17 July 2008

\begin{abstract}
In 1856, one (or two) destructive earthquake(s) occurred off Djijelli (Algeria) and probably triggered a tsunami in the western Mediterranean Sea. Following recently published results of marine campaigns along the North-Algerian margin, a new source hypothesis for the earthquake has been proposed, and is constituted with a set of three "en échelon" fault segments positioned in agreement with previous studies of this earthquake and with macroseismic data available. The geometrical parameters for this source, in agreement with a $\mathrm{Mw}=7.2$ earthquake, display an average $40^{\circ} \mathrm{NW}$ dip, a $80^{\circ}$ strike and mean dimensions of $80 \mathrm{~km}$ (length) $\times 20 \mathrm{~km}$ (width). A coseismic slip of $1.5 \mathrm{~m}$ is consistent with an average convergence rate of about $5-6 \mathrm{~mm} / \mathrm{yr}$ and a recurrence period of 300-400 years. They are then introduced in the tsunami modelling code to study the propagation across the Mediterranean Sea with a special attention towards the Balearic Islands. A focus on the two major towns, Palma (Majorca) and Mahon (Minorca) Harbours shows that these places are not the most exposed (maximum water heights less than $1 \mathrm{~m}$ ) by tsunami waves coming from this part of the African margin. Specific amplifications revealed by modelling occur off the southern coast of Minorca and the southeastern coast of Majorca, mostly related to submarine bathymetric features, and are able to produce coastal wave heights larger than 1 to $2 \mathrm{~m}$ as offshore Alcalfar (Minorca). A deep submarine canyon southward Minorca leads to the amplification of waves up to two times on both sides of the canyon. However these modellings could not be compared to any historical observations, non-existent for these sites. This work is a contribution to the study of tsunami hazard in western Mediterranean based on modelling, and offers a first assessment of the tsunami exposure in the Balearic Islands.
\end{abstract}

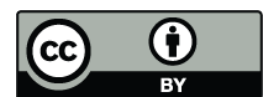

Correspondence to: J. Roger (jean.roger@cea.fr)

\section{Introduction and objectives}

On 21 May 2003, a $\mathrm{M}_{w} 6.8$ earthquake located about $50 \mathrm{~km}$ east of Algiers (Algeria) triggered a moderate tsunami in the western Mediterranean Sea that provoked significant seiches, leading to local floodings and damage essentially on boats, in several harbours in the Balearic Islands (Ayadi et al., 2003; Alasset et al., 2006) (see http://www.elmundo.es/elmundo/ 2003/05/22/sociedad/1053590416.html for example). This event reminded us that areas apparently (and recently) poorly prone to tsunami hazard, but with a significant tectonic activity, likely already experienced tsunami events, even though probably rare and moderate (Meghraoui et al., 2006).

The 2003 event benefited from modern seismological and geodetic records, thus the earthquake source has been debated to describe the fault rupture (Yelles et al., 2004; Delouis et al., 2004; Semmane et al., 2005; Braunmiller and Bernardi, 2005), the slip distribution (Delouis et al., 2004; Yelles et al., 2004) and the surrection observed along the coast (Delouis et al., 2004; Meghraoui et al., 2004). The tsunami observations at tide gauges were quite sparse and of poor quality, except in the Balearic Islands where the records allowed to discuss the earthquake source (Alasset et al., 2006).

By contrast, historical events in the northern Algerian margin that could have triggered tsunamis in the western Mediterranean Sea are not well known, but the sequence of events at least goes back to the Algiers earthquake in 1365 (Yelles, 1991). Among the historical events, one of the most significant and recent tsunami originating from northern Algeria was provoked by the 21-22 August 1856 seismic sequence that struck the area of Djijelli. In the following we discuss this earthquake sequence and the tsunami that it triggered, especially in the Balearic Islands where no observation is available except one reported in Mahon Harbour (Rothé, 1950) whose robustness is questionable. We first recall the general tectonic setting and the historical data

Published by Copernicus Publications on behalf of the European Geosciences Union. 


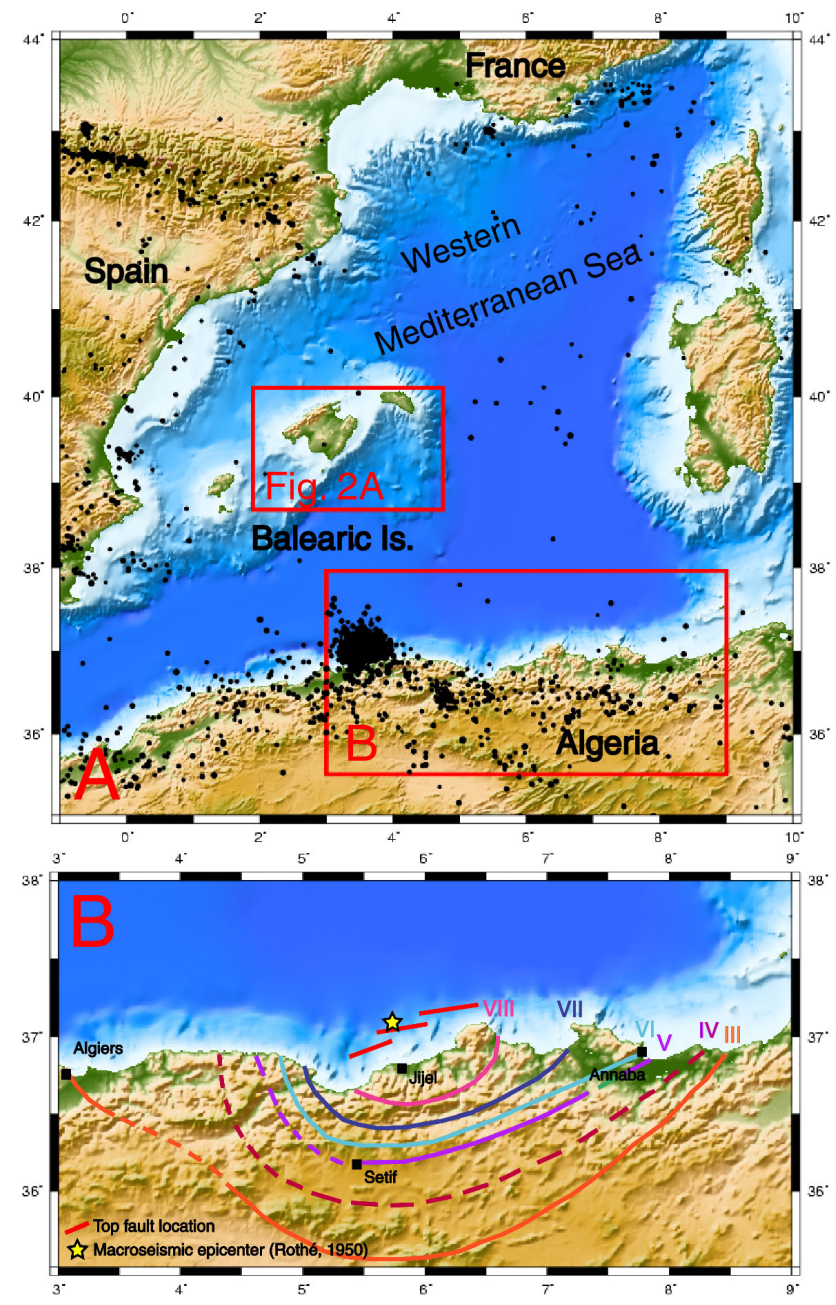

Fig. 1. (A) Geographical location of the study area in Western Mediterranean Sea and local seismicity from EMSC indicating the location of the plate boundaries. The zoom (B) shows the location of the 3 fault segments (in red) over GEBCO 1' shaded bathymetry and topography map of Djijelli area and isoseismal curves (MSK intensity scale) from Harbi et al. (2003). Location of Fig. 2A is reported. A represents the domain of the computational grid 0 .

describing the event. Then we use tsunami numerical modelling to test different hypotheses allowing to discuss the earthquake source, and finally draw several conclusions regarding tsunami hazard in the Balearic Islands.

\section{General settings}

\subsection{Geological context}

The Mediterranean Sea is located at the boundary of two main tectonic plates, Europe and Africa. Their collision gives rise to a high seismicity level which is, in its western domain, essentially expressed in a moderate diffused seismic area, in northern Africa (Fig. 1A). Northern Algeria is part of this collision zone, where recent geodetic studies indicate an actual plate convergence rate of about $5.0 \pm 1 \mathrm{~mm} / \mathrm{yr}$ in a $\mathrm{N} 60^{\circ} \mathrm{W}$ direction (Calais et al., 2003; Nocquet and Calais, 2003, 2004; Serpelloni et al., 2007).

Earthquakes with magnitude $\mathrm{Mw}>5$ frequently occur in the area (Harbi et al., 1999; Aoudia et al., 2000; Peláez Montilla et al., 2003), sometimes inducing important destructions and casualties (Adams and Barazangi, 1984). Well studied thrusting earthquakes essentially occur onshore, as for instance the largest recorded Ms7.3 1980 El Asnam earthquake (Ruegg et al., 1982; Deschamps et al., 1982; Meghraoui et al., 1988; Bezzehgoud et al., 1995).

According to available catalogues, tsunamis are frequent in Mediterranean and associated with both earthquakes and/or underwater landslides occurring on margins with steep slopes (Maramai et al., 2003; Papadopoulos and Fokaefs, 2005). Although North Algerian margin is not positioned above a subduction zone, many earthquakes and landslides along the margin are recorded each year and some destructive tsunamis have been reported over the past 700 years, 3 coming from great earthquakes in 1365, 1856 and 2003 (Yelles, 1991; Mokrane et al., 1994; Soloviev et al., 2000; Tinti et al., 2001; Alasset et al., 2006).

Recent studies along the Algerian margin have greatly improved the knowledge of the active structures (Domzig, 2006; Domzig et al., 2006; Yelles et al., submitted ${ }^{1}$ ). They bring to light the presence of compressional deformation features during the Quaternary period with inverse faults (pure compressive deformation) and strike slip faults leading to a clear seismogenic zone along the margin (Domzig, 2006).

The tsunamis generated during contemporary offshore earthquakes could have huge consequences on the Algerian coast which is considered as "near field" (less than $100 \mathrm{~km}$ ) (Yelles et al., submitted ${ }^{2}$ ). But it could also have consequences in the Balearic Islands especially in harbours/bays where site effects are commonly frequent and where paper reports (see http://www.elmundo-eldia.com/2003/05/22/ illes_balears/1053611977.html for example) mention non negligible wave arrivals up to $1 \mathrm{~m}$ high in 2003. And it is also worth mentioning here that some harbours in Balearic Islands located all along the southern coastline of Minorca and Majorca, as well as Mahon, Ciutadella or Palma, have been damaged in 2003, and that they are also prone to rissaga phenomenon i.e. meteorological tsunamis. In particular they can exhibit special behaviour to tsunami arrival, directly due

\footnotetext{
${ }^{1}$ Yelles, K., Domzig, A., Déverchère, J., Bracène, R., Mercier de Lépinay, B., Bertrand, G., Boudiaf, A., Winter, T., Kherroubi, A., Le Roy, P., and Djellit, H.: Evidence for a large active fault offshore West Algiers, Algeria, and seismotectonic implications, Geophys. J. Int., submitted.

${ }^{2}$ Yelles, K., Roger, J., Déverchère, J., Bracène, R., Domzig, A., Hébert, H., and Kherroubi, A.: The tsunami of Djijelli (Eastern Algeria) of 21-22nd August 1856: seismotectonic context, modelling, and implications for the Algerian coast, submitted to Pure and Applied Geophysics, Topical Issue on Tsunamis, submitted.
} 
to their natural oscillation mode or to the resonant oscillation of the water body, inducing the so-called seiche (Monserrat et al., 1991; Gomis et al., 1993; Rabinovich and Monserrat, 1996 and 1998; Liu et al., 2003; Jansa et al., 2007).

It probably also could have consequences in southern France in the Golfe du Lion area where the slope of the continental shelf is rather low, or in the Côte d'Azur harbours too, where several witness accounts report oscillations and eddies in several harbours consecutive to the 2003 Zemmouri earthquake and associated tsunami (A. Sahal, pers. comm., 2007).

\subsection{Historical facts}

On the 21st and 22nd of August 1856 two earthquakes occurred near the Algerian coastal town of Djijelli about $300 \mathrm{~km}$ east to Algiers (Fig. 1B). The second one has an estimated magnitude $\mathrm{Ms}=5.7( \pm 0.17)$ and an intensity $\mathrm{I}_{0}=\mathrm{VIII}$ MSK according to Harbi et al. (2003). It constitutes the best documented earthquake of North-East Algeria, described in many historical scientific reports and press articles. The quake was felt up to Nice (FR) and Genoa (IT). This couple of events has generated one (or two) tsunami wavetrains, which consequences added to earthquake damage and casualties along the Algerian coast and which are reported in bibliography (Gaultier de Claubry, 1856; Aucapitaine, 1856; De Senarmont, 1856; Ambraseys, 1982; Harbi et al., 1999; Harbi, 2001; Antonopoulos, 1990; Yelles Chaouche, 1991).

Unfortunately, as previously mentioned, no detailed reports are available concerning a potential Mediterranean Seawide tsunami. Only one possible effect is mentioned in Mahon Harbour in the Balearic Islands, but it cannot be ruled out that it may be related to a storm observed these days in the Western Mediterranean (reported in historical papers as La Gazette du Midi, ${ }^{\circ} 7272$, 22nd August 1856 or Le Moniteur Universel, 25th August 1856). Also, as usual for offshore earthquakes, and especially for historical events, the location and size of the source are difficult to assess from macroseismic data as mentioned by Harbi et al. (2003).

The main characteristics of the tsunami related to the two events of 1856 are summarized in Table 1. Firstly we observe from these data that there was an important flooding and a sea withdrawal following the earthquakes, which induced more or less damage along the Algerian coast and in the Balearic Islands. Secondly it is also worth noting that there is no reported information concerning tsunami estimated arrival times in historical data.

\section{Numerical modelling}

\subsection{Sources definition}

Firstly potential sources able to have generated the 1856 earthquake(s) and associated tsunami must be investigated. According to the fact mentioned by Harbi et al. (2003) that damage became more and more important and numerous as
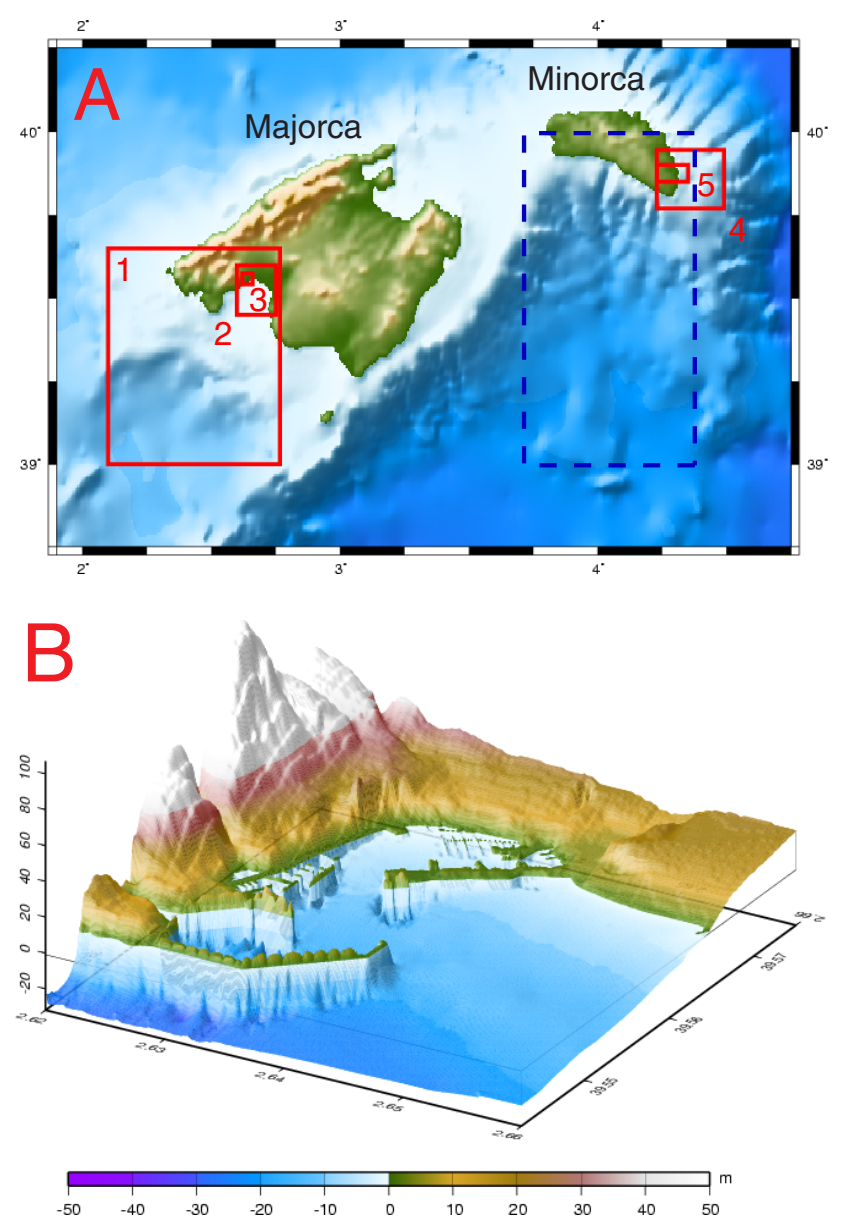

Fig. 2. (A) (localized in Fig. 1) shows the different levels of grid used in modelling (in red) and a special focus on a submarine canyon (in dashed blue); (B) represents the 3-D visualization of the high resolution grid $(10 \mathrm{~m})$ of Palma harbour (grid 3$)$.

approaching the coastline, and confirmed by the isoseismal maps issued from historical reports for the 1856 event, a sealocated source offshore Djijelli has constantly been proposed (Harbi et al., 2003; Harbi et al., 1999) (Fig. 1B).

In addition, according to Ambraseys (1982) and Harbi et al. (2003), the main shock has been felt over a wide area welloriented towards French Riviera and north-western Italia (esp. Nice and Genoa) as mentioned above. The lack of observations in the inner part of Algeria is mostly due to the low population density in desert areas, and put some uncertainties to the southernmost extent of macroseismic effects. Nevertheless the coastal extent of these effects is not influenced by these missing observations to the south, and the sum of all the information gathered from intensity map, isoseismal curves geometry, earthquake felt area, tsunami generation, etc., allow us to propose a source of about $100 \mathrm{~km}$ length. This, according to Stock and Smith (2000), corresponds to an Mw $=7.0-7.2$ earthquake, i.e. the required magnitude to generate such a destructive tsunami, significantly larger than the 2003 event. 
Table 1. Historical data set compiled from Gaultier de Claubry (1856), Aucapitaine (1856), De Senarmont (1856), Ambraseys (1982), Harbi et al. (1999), Harbi (2001), Antonopoulos (1990), Yelles Chaouche (1991).

\begin{tabular}{|c|c|c|c|}
\hline Mentioned Town in reports & 1st earthquake & 2nd earthquake & remarks \\
\hline Djijelli (Jijel, Algeria) $5.75^{\circ} \mathrm{E}, 36.81^{\circ} \mathrm{N}$ & $\begin{array}{l}\text { A little harbour is severely damaged } \\
\text { at the western extremity of the bay; } \\
\text { water came back suddenly after a first } \\
\text { sea withdrawal flooding low parts of } \\
\text { the coast }\end{array}$ & $\begin{array}{l}2-3 \mathrm{~m} \text { high wave; several back and forth; } \\
\text { sea stays troubled during } 3 \text { days; the town } \\
\text { is destroyed by the earthquake }\end{array}$ & $\begin{array}{l}\text { Concerning the 1st earthquake, } \\
\text { it is unclear whether it is the shock } \\
\text { or the tsunami which caused reported } \\
\text { destructions }\end{array}$ \\
\hline Mahon (Minorca) $4.26^{\circ} \mathrm{E}, 36.88^{\circ} \mathrm{N}$ & $\begin{array}{l}\text { Rapid flooding of the harbour; a lot } \\
\text { of boats break their moorings }\end{array}$ & & $\begin{array}{l}\text { Witnesses probably do not make } \\
\text { the distinction between the } 2 \\
\text { different waves arrivals }\end{array}$ \\
\hline $\begin{array}{l}\text { Philippeville (ancient name for Skikda) } \\
6.90^{\circ} \mathrm{E}, 36.87^{\circ} \mathrm{N}\end{array}$ & & $\begin{array}{l}\text { Sea level draw down suddenly and rise up } \\
\text { gradually of about } 0.6 \mathrm{~m}\end{array}$ & \\
\hline Bougie (actual Bejaia) $5.07^{\circ} \mathrm{E}, 36.74^{\circ} \mathrm{N}$ & & $\begin{array}{l}\text { Several series of waves have flooded } \\
\text { the coast; sea level has increased of } \\
\text { about } 5 \mathrm{~m} \text { ( } 3.75 \mathrm{~m} \text { for some authors); } \\
\text { coast has been flooded ( } 5-6 \text { times } \\
\text { only } 3 \text { times for Aucapitaine, } 1856) \\
\text { with a withdrawal of } 35 \mathrm{~m}\end{array}$ & \\
\hline Bone (actual Annaba) $7.75^{\circ} \mathrm{E}, 36.90^{\circ} \mathrm{N}$ & & $\begin{array}{l}\text { Sea level rose for } 1 \mathrm{~m} \text {; flood and agitated } \\
\text { sea during } 12 \mathrm{~h} \text {; a little isle seems to have } \\
\text { disappeared under sea. }\end{array}$ & $\begin{array}{l}\text { Witnesses probably do not make } \\
\text { the distinction between the } 2 \\
\text { different waves arrivals }\end{array}$ \\
\hline $15 \mathrm{mi} \mathrm{N} 7^{\circ} \mathrm{E}$ from Jijel on the boat "Tartare" & & & Extreme violence quake \\
\hline $\begin{array}{l}\text { Coasts of Sardinia, Nice, Malta, Mahon, } \\
\text { Carloforte, Iglesias and San Petro Sardinia }\end{array}$ & & & $\begin{array}{l}\text { Additional locations where the quake } \\
\text { could have been felt (Rothé, 1950) }\end{array}$ \\
\hline
\end{tabular}

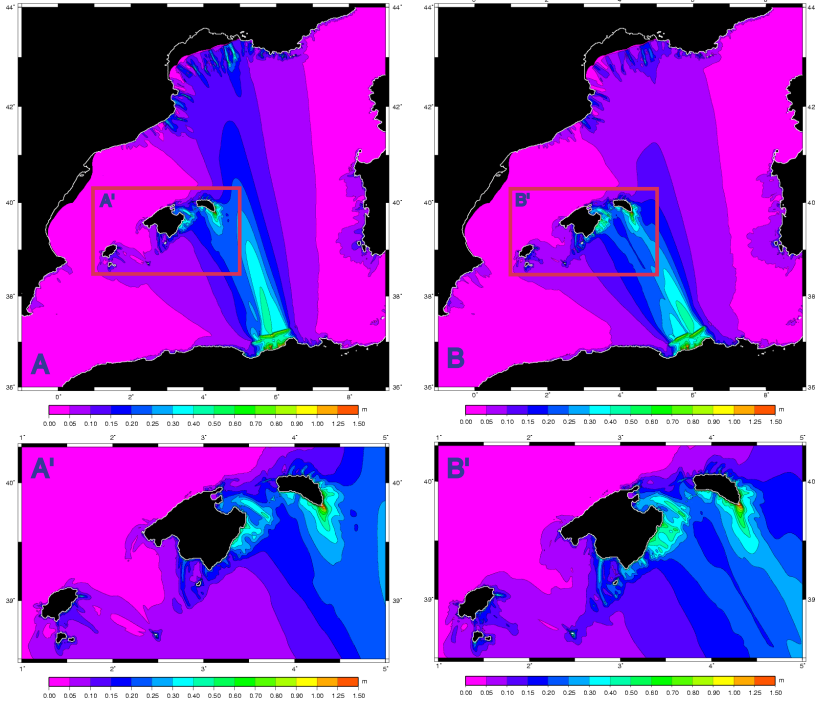

Fig. 3. Maximum wave heights cumulated on $1.5 \mathrm{~h}$ after the rupture involving the 3 segments simultaneously, with a mean strike of $80^{\circ}$ (left, $\mathrm{A}$ and $\mathrm{A}^{\prime}$ ) or $60^{\circ}$ (right, B and $\mathrm{B}^{\prime}$ ).

As said before, recent results from bathymetric and seismic MARADJA survey (Domzig, 2006) allowed us to propose potential sources (earthquake fault plane location) for the Djijelli tsunami of 21-22 August 1856. In fact Domzig (2006) indicates a fault system "en echelon" offshore Djijelli composed of at least three faults parallel to the coast dipping south-eastward (Fig. 1B). This source system seems to be in good agreement with the isoseismal map of Harbi et al. (2003) and with the earthquakes localization $\left(37.10^{\circ} \mathrm{N}-5.70^{\circ} \mathrm{E}\right)$ from Rothé (1950, USGS/NEIC earthquakes catalogue). The mean strike of these three faults is well-oriented: Okal (1988) recalls that in the case of a tsunami generated by an earthquake, the maximum wave amplitudes are always localized in the major direction of deformation, i.e. an inverse fault with a $90^{\circ}$ rake angle should generate a tsunami with maximum height in the direction perpendicular to the fault direction.

\subsection{Modelling parameters of the 3 sources}

In order to model the tsunami, we propose parameters for three segments (Table 2), able to generate an $\mathrm{M}_{w}=7.2$ earthquake, if they ruptured together. We have to put minimum conditions to fit the inferred seismic moment $\mathrm{M}_{0}$, related to fault geometry through the law $\mathrm{M}_{0}=\mu \mathrm{SLW}$ (where $\mu$ is the rigidity, $\mathrm{S}$ the average slip, $\mathrm{L}$ the fault length and $\mathrm{W}$ the fault width). In order to explain the observations in Northern Algeria we also tested our solution for local sites (YellesChaouche et al., 2007).

An $M_{w} 7.2$ earthquake corresponds to $\mathrm{a}_{o}=1 * 10^{10}$ N.m (Aki, 1966), and, according to Stock and Smith (2000) and Wells and Coppersmith (1994), to a fault rupture length of $70-80 \mathrm{~km}$ and to a surface displacement of about $1-1.5 \mathrm{~m}$. But they show that normally, in a subduction zone, length and 
width must be in a ratio of 1 to 3 . However fault widths larger than $20 \mathrm{~km}$ and longer than $40 \mathrm{~km}$ are not consistent with the structures identified here (Domzig, 2006), thus a source involving several segments has to be considered. The fault strike is chosen in accordance with the geomorphologic interpretation of the region by Domzig (2006): we use a mean strike of $80^{\circ}$. However the real geological strike in depth may differ from the seismological strike by $20^{\circ}$ (Déverchère, pers. comm.), thus a $60^{\circ}$ strike angle was also tested.

The recent seismic studies presented by Domzig et al. (2006) and Harbi et al. (1999) allow us to propose a depth of fault centre of about $10 \mathrm{~km}$, and a dip of $40^{\circ}$ in this study.

According to historical reports and to actual deformation measurements (Calais et al., 2003; Nocquet and Calais, 2003, 2004) indicating an average convergence rate of about 5$6 \mathrm{~mm} / \mathrm{yr}$ in this region, we are able to propose a coseismic slip of $1.5-2 \mathrm{~m}$ which could be reached after $300-400$ years (Hébert et al., 2007a). As for the rigidity, we assume a standard rigidity of $4.5^{*} 10^{10} \mathrm{~N} . \mathrm{m}^{2}$ (compression mechanism) in agreement with Bilek and Lay (1999) and Geist and Bilek (2001) for conventional earthquakes.

\subsection{Deformation and Tsunami Modelling}

The initial deformation calculus is based on elastic dislocation computed through Okada formula (1985). Our method considers that the sea-bottom deformation is transmitted without losses to the entire water column, and solves the hydrodynamical equations of continuity (1) and motion (2) conservation. Non linear terms are taken into account, and the resolution is carried out using a Crank Nicolson finite difference method centred in time and using an upwind scheme in space. This method has been widely used in the Pacific Ocean and contributed to tsunami hazard studies in several locations (Hébert et al., 2001, 2007b).

$$
\begin{aligned}
& \frac{\partial(\eta+h)}{\partial t}+\nabla \cdot[v(\eta+h)]=0 \\
& \frac{\partial v}{\partial t}+(v \cdot \nabla) \cdot v=-g \nabla \eta
\end{aligned}
$$

$\eta$ corresponds to the water elevation; $h$ to the depth; $v$ to the horizontal speed vector; $g$ to the gravity.

The wave propagation is calculated on 4 levels of imbricated grids of increasing resolution for Majorca (allowing to focus on Palma harbour) and 3 levels for Minorca (allowing to focus on Mahon inlet) (Figs. 1 and 2). The larger grid (0), corresponding to geographical coordinates of Fig. 1A, is built from GEBCO World Bathymetric Grid 1' (British Oceanographic Data Center, 1997) and is just an interpolation of this grid at a space step of $500 \mathrm{~m}$. The grid resolution increases close to the studied site i.e. when the water depth $h$ decreases along with the tsunami propagation speed equation $c=\sqrt{g h}$ that depends only on $h$ in non dispersive assumption.

High resolution grids, which are set up for the final grid level, are made from digitized, georeferenced and interpolated nautical bathymetric charts and/or multi-beam bathy-
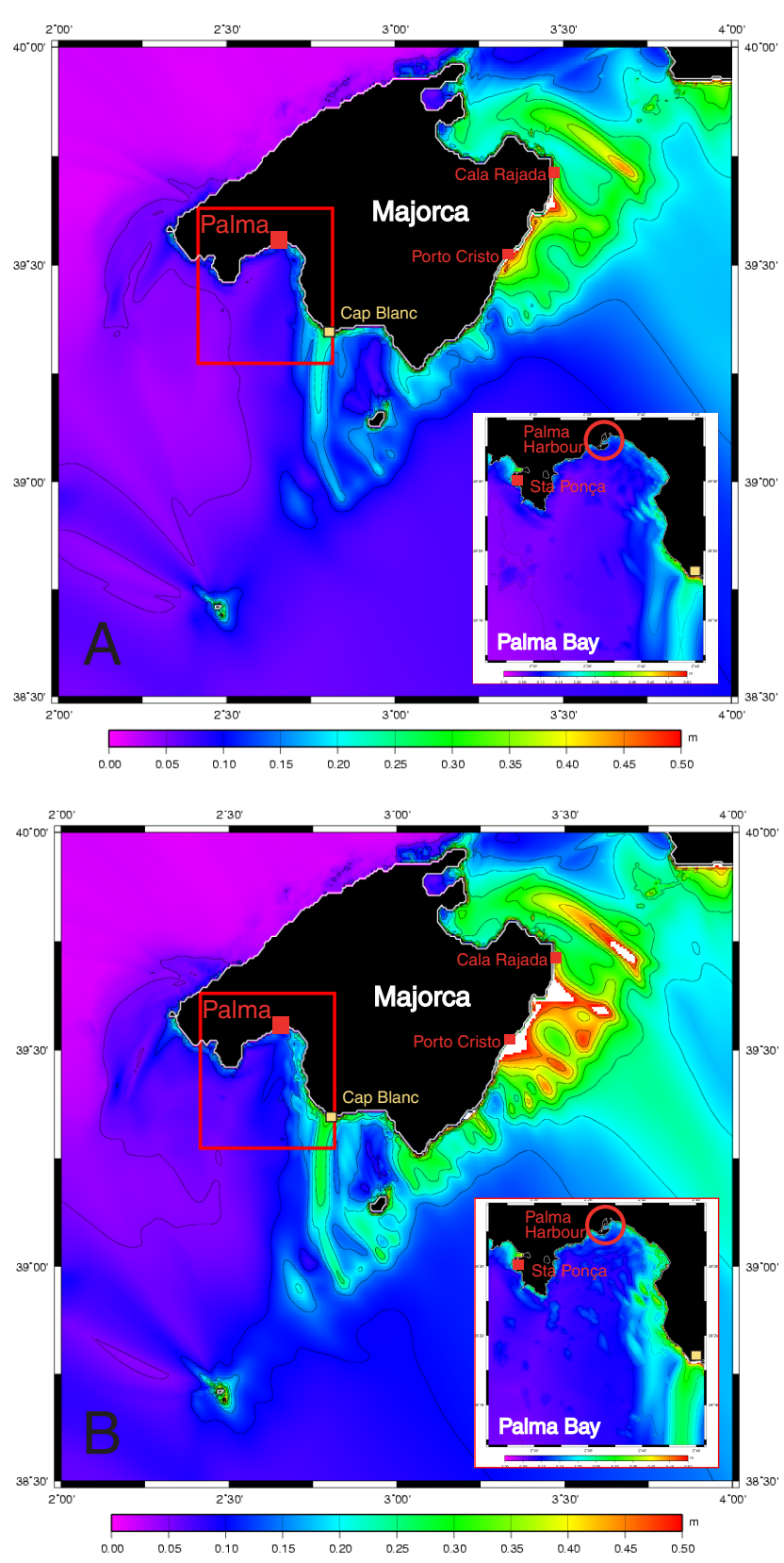

Fig. 4. Majorca Island and zoom on Palma Bay and neighbourhood for a $80^{\circ}$ strike source (A) and a $60^{\circ}$ strike source (B).

metric data. For Palma harbour (Majorca), the grid has a resolution of $10 \mathrm{~m}$ (grid 3) able to reproduce harbour major infrastructures as docks or piers (Fig. 2B) which could have a significant influence on wave arrival times and amplitudes. In order to reproduce these structures at best, and not to put a low slope where there is a vertical wall, we have digitized the bathymetric map of the harbour in agreement with available harbour pictures to complete the lack of bathymetric values near these structures. Intermediate grids 1 and 2 are made with both datasets from grid 0 and 3 and data coming from 
Table 2. Geographical and geometrical parameters of the 3 fault segments used for the modelling of the initial deformations of seafloor. The two values of strike angle are those tested in the study.

\begin{tabular}{llcccccccccccc}
\hline & $\begin{array}{l}\text { Longi- } \\
\text { tude }\left(^{\circ}\right)\end{array}$ & $\begin{array}{l}\text { Lati- } \\
\text { tude }\left({ }^{\circ}\right)\end{array}$ & $\begin{array}{c}\text { Depth of } \\
\text { the fault } \\
\text { center }(\mathrm{km})\end{array}$ & $\begin{array}{c}\text { Slip } \\
(\mathrm{m})\end{array}$ & Strike $\left(^{\circ}\right)$ & Dip $\left(^{\circ}\right)$ & Rake $\left(^{\circ}\right)$ & $\begin{array}{c}\text { Length } \\
(\mathrm{km})\end{array}$ & $\begin{array}{c}\text { Width }(\mathrm{km}) \\
\text { modulus }(\mathrm{Pa})\end{array}$ & $\begin{array}{c}\text { Shear } \\
(\mathrm{Nm})\end{array}$ & $\mathrm{M}_{w}$ & $\mathrm{M}_{0}$ \\
\hline west & 5476 & 36950 & 10 & 1.0 & $75(55)$ & 40 & 90 & 25 & 20 & $4,5^{*} 10^{10}$ & 6.8 & $2.2^{*} 10^{19}$ \\
center & 5736 & 37080 & 10 & 1.5 & $85(65)$ & 40 & 90 & 37 & 20 & $4,5^{*} 10^{10}$ & 7.1 & $5^{*} 10^{19}$ \\
\hline east & 6.150 & 37.178 & 10 & 1.5 & $75(55)$ & 40 & 90 & 44 & 20 & $4,5^{*} 10^{10}$ & 7.1 & $5.9^{*} 10^{19}$ \\
\hline
\end{tabular}

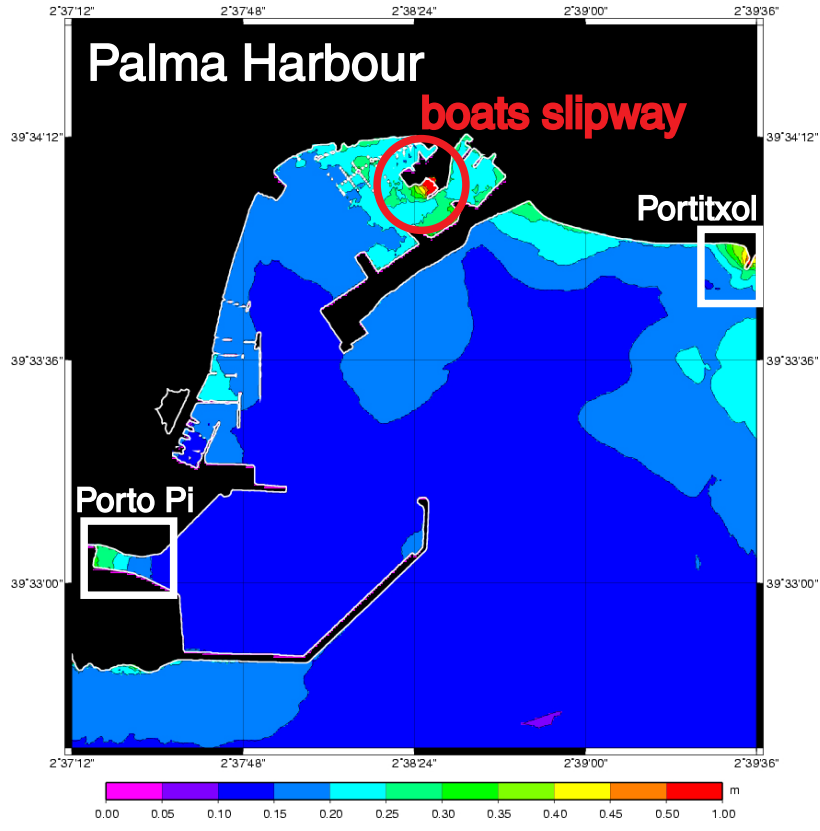

Fig. 5. Maximum wave heights for a $60^{\circ}$ strike source: zoom on Palma Harbour.

multi-beam Spanish campaigns (de Mol, personal communication). Grid 1 has been chosen to be $120 \mathrm{~m}$ resolution and grid 2 to be $30 \mathrm{~m}$ resolution in order to never have more than a factor of $4-5$ between imbricated grids, so that the shoaling effect is well reproduced and the wavelengths properly sampled. The process for Mahon is similar, leading to grids 4 (resolution $120 \mathrm{~m}$ ) and 5 (resolution $30 \mathrm{~m}$ ) imbricated in grid 0 .

\subsection{Results}

\subsubsection{Overview}

The first results of numerical modelling of the 1856 tsunami propagation towards the Balearic Islands exhibit several interesting features (Fig. 3). Firstly, the value of the fault strike, all other parameters being equal, is clearly discriminatory as regards the areas impacted. With a $80^{\circ}$ angle (Fig. 3A) the tsunami propagation is more oriented towards Southern France (Golfe du Lion) whereas a $60^{\circ}$ oriented fault system (Fig. 3B) leads to a propagation principally towards the Balearic Islands, excluding Ibiza and Formentera which seem poorly threatened by a tsunami coming from this part of North-African margin (Roger and Hebert, 2007). This results contrasts with the 2003 event, which led to destructions along the coasts of these two islands (Perez, pers. comm.), and for which numerical modellings clearly confirmed the exposure of Ibiza and Formentera for this source area. Hereafter, detailed modellings for these two islands are thus discarded.

The results also indicate that some sites, principally along the eastern coast of Majorca and the South-East peninsula of Minorca, are particularly more reactive to tsunami wave arrivals and to their amplification, whatever the strike angle $\left(60^{\circ}\right.$ or $\left.80^{\circ}\right)$ : maximum wave height reaches $1 \mathrm{~m}$ and much more at some points (especially in Minorca) (Fig. 3A and $\mathrm{B})$, and are on average are slightly larger with a $60^{\circ}$ strike (Fig. 3B') than with a $80^{\circ}$ (Fig. 3A).

\subsubsection{Majorca}

The result of modelling on Majorca shows non negligible heights (more than $40 \mathrm{~cm}$ ) along the South-East to NorthEast coast of Palma Bay (Fig. 4). The waves seem to be amplified along particular ways where they may be guided and more amplified, in the South-East of Palma Bay in front of Cap Blanc and also in the North-Eastern part of the island (Fig. 4). A detailed study of the results in the higher resolution grids reveals that some particular points as in the small bay of Santa Ponça, westward to Palma (Fig. 4) are reached by large wave heights, all the more as the grid resolution is increased. It is to note that this bay is part of the bays which are inclined to the rissaga phenomenon frequent in the Balearic Islands (Monserrat et al., 2006).

Concerning Palma Harbour, actually located in the northwestern part of the bay (Fig. 4), the modelling results for the $10 \mathrm{~m}$ resolution grid (for a $60^{\circ}$ strike angle) show that wave amplification higher than $1 \mathrm{~m}$ takes place at the far end of the harbour (Fig. 5). The run-up computation of this last level of imbricated grid shows that only one inundation is modelled in the harbour, on a boat slipway in the very inner part of the harbour and that the little dock of Porto Pi shows local amplification as the little Marina of Portitxol outside Palma Harbour (Fig. 5). 


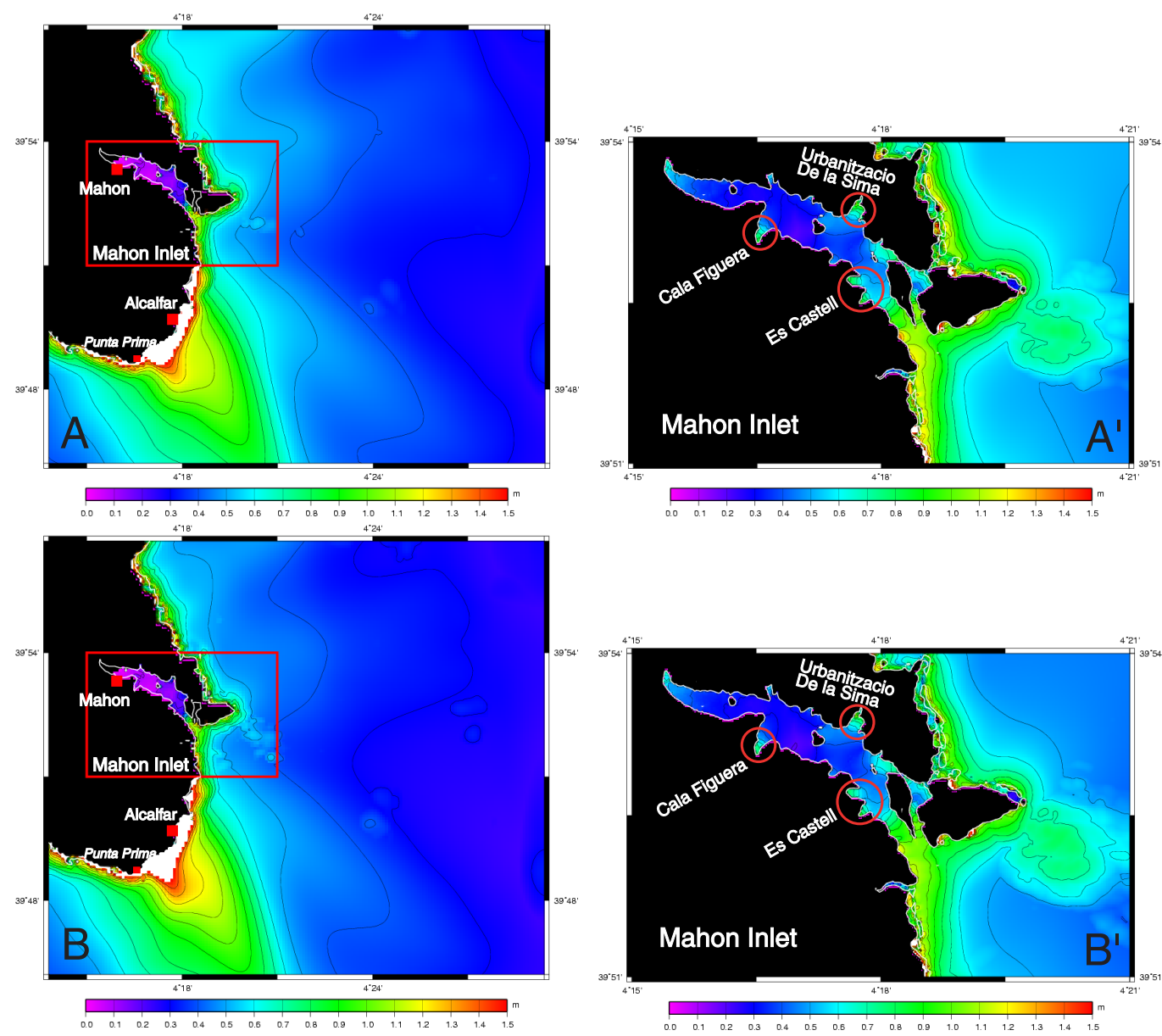

Fig. 6. Maximum wave heights along the South-eastern coast of Minorca Island for a $80^{\circ}$ strike source (A) and a $60^{\circ}$ strike source (B). In both cases there is a zoom on Mahon Inlet pointing out some particular areas (A' and $\left.\mathbf{B}^{\mathbf{\prime}}\right)$. Be careful that there is no calculated inundation, the white colour indicates only maximum wave heights above $1.5 \mathrm{~m}$.

\subsubsection{Minorca}

As previously seen for Majorca, we notice that the waves seem to be amplified along particular ways approaching Minorca (Fig. 3). In addition, the results in the finer grids clearly show that maximum wave heights of more than $1.5 \mathrm{~m}$ are reached off the South-East extremity of Minorca.

Mahon Inlet seems to be rather protected from the modelled tsunami arrivals (Fig. 6A and B). The modellings performed on higher resolution $(30 \mathrm{~m})$ grids (grid 5) enhance wave amplification in the inlet but restricted to smaller bays included in the inlet as Cala Figuera, Es Castell or Urbanitzacio De la Sima (Fig. 6A' and 6B'). Thus the computation on this higher resolution grid allows us to make a more detailed analysis of this site certainly closer to the reality: the entrance of the inlet is better modelled with a $30-\mathrm{m}$ pixel than with a $120-\mathrm{m}$ pixel, allowing to better image this $500-\mathrm{m}$ wide entrance and so to let long waves penetrate it.

\section{Discussion}

The paucity of observations on remote coastal sites precludes us to discuss the source based on tsunami data, but we can propose the following scenario for the 1856 event. Two main shocks have been reported, the second being the strongest according to historical reports. Firstly the western proposed segment ruptured on 21st August, with a cautious interpretation of historical data which indicates that the magnitude of the first earthquake was certainly low. Then both eastern segments proposed here, based on recent geological investigations (Domzig, 2006), could have broken on 22nd August and generated an earthquake with magnitude sufficient to have important consequences over a wide area in agreement with isoseismal maps from Harbi et al. (2003) and to generate a sea-wide tsunami (explaining the observation in Mahon inlet, Balearic Islands). The modelling results at the Mediterranean scale (Fig. 3) confirm that Minorca is mostly impacted by the two eastern segments, and indeed the modelling of the 


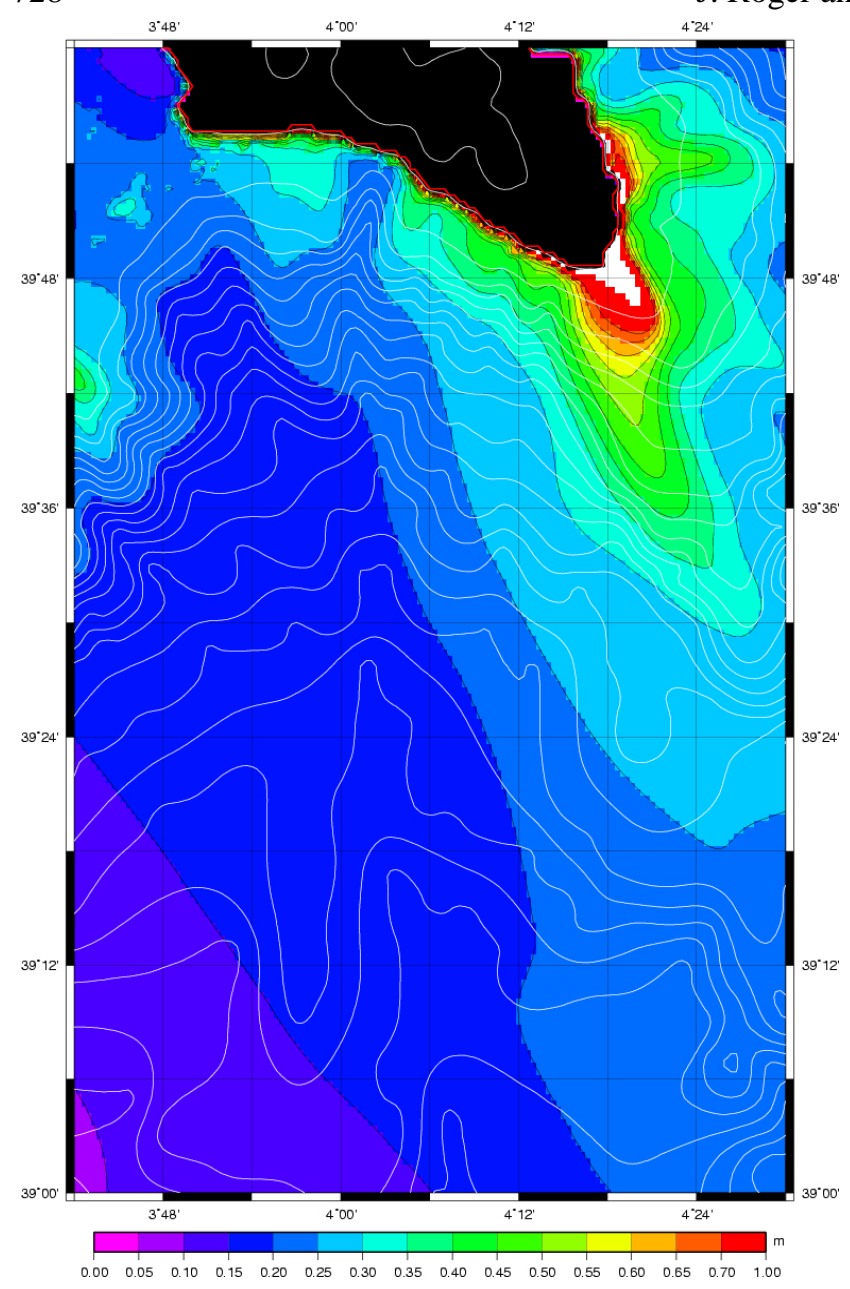

Fig. 7 Maximum wave heights for a $80^{\circ}$ strike source onto bathymetric map southward Minorca (isocontour $100 \mathrm{~m}$ ) that reveals the importance of the role of a submarine canyon (Minorca Canyon system) on the wave amplification.

western segment alone did not produce waves able to reach Minorca (Yelles-Chaouche et al., 2007).

Concerning the tsunami impact, first important differences are noted for Majorca, depending on the strike of the source, leading to sites more impacted along the coast of Palma Bay for a $60^{\circ}$ strike than for a $80^{\circ}$ strike (Fig. 3). Palma Harbour and Town are situated at the extreme North-West of the bay, and are the economical and touristy centre of the Balearic Islands. Our results indicate that these places are not much affected by tsunamis generated in the 1856 epicentral area (Figs. 4 and 5). On one hand the lack of historical reports concerning a tsunami in Palma in 1856 is consistent with our results. However the shape of the harbour including the location of piers was probably different from now and then our model may probably not represent exactly the resonant effect of the Palma Bay at that time, and especially the harbour resonance put in evidence after studying rissaga phenomenon (Monserrat et al., 2006 for example) or more simply the long wave arrival effects (Bellotti, 2007). A site as Palma Bay which can easily respond to atmospheric variations with non negligible oscillations is supposed to have a particular reaction like strong amplification (resonance) to long wave such as earthquake-induced tsunami (Jansa et al., 2007); concerning "classic" seismic long-waves, the work done on coastal structures studies indicates that this phenomenon can be reduced today taking into account the position and shape of the harbours entrance (Bellotti, 2007; Nakamura and Takayuki, 2003; Nakamura et al., 2000).

Regarding Minorca, whatever the strike, the modelling results of wave amplifications, and location of these amplifications, are rather the same (Figs. 3 and 6). A more detailed analysis reveals that the southernmost area offshore Minorca (offshore Alcalfar and Punta Prima) seems to considerably amplify wave heights, probably due to the shape of the bathymetry (Fig. 6A and 6B). In both cases we have almost the same results considering locations and amplitudes. According to modelling, Mahon inlet is not particularly receptive to long waves except in some little bays within the inlet (Fig. 6A' and 6B'), despite the fact that this places is frequently prone to rissaga phenomenon which waves direction and propagation speed are conducive to produce a resonant response and so naturally amplify them. Since the Balearic Islands and particularly inlets as Cuitadella (Western coast of Minorca) and Mahon or bays as Palma Bay are frequently inclined to rissaga phenomenon (meteorological tsunami that could be generated by strong jump in atmospheric pressure, gravity waves or other atmospheric sources) (Monserrat et al., 1991, 2006; Liu et al., 2003; Rabinovich and Monserrat, 1998; Gomis et al., 1993) we have to underline the important probability of site effects in these specific Balearic sites.

The site effects are thus very important to be mentioned in case of such a tsunami, which is among the strongest hazards expected in the area. We can observe a sea level variation of $2 \mathrm{~m}$ in a bay and nothing due to resonance/amplification phenomenon in the surrounding areas.

A particularly impressive phenomenon of long wave trapping shown on Fig. 3 is underlined in both tested cases in Minorca Island southward of Mahon Inlet (Fig. 6A and 6B). A less impressive phenomenon is also visible on the southeastern coast of Majorca (Fig. 4A and 4B). Actually additional tested seismic sources generating tsunamis in a zone from eastern Algeria to southern Sardinia (Roger and Hébert, 2007) induced such an amplification which is due to the particular V-shape of the bathymetry in this area, with slowly increasing depths. Concerning the inlet case no important amplifications occur in the modelling (Fig.6 A' and B'), although there are some reports of rissaga phenomenon in this place. Then we can suppose that either the resonant frequency of the inlet is probably not completely taken into account by our method, at least at this scale or that the tsunami frequency is different from the rissaga's one. However similarities of wavelengths and periods between seismic tsunami and atmospheric tsunami (Monserrat et al., 2006) allow to assume that a harbour or a bay frequently affected by the 
rissaga phenomenon should react the same in the case of a seismic tsunami arrival.

In 1856, the density of populated areas in coastal Balearic locations, such as in the southern part of Minorca, is not well known. Available older historical cartographic documents (Seutter, 1741) only indicate a few settlements. Even though this population may have very locally increased in the 19th century, this rather low density did not favour numerous reports of possible observations. However modelling results indicate that this part of the islands is one of the more stricken ones by long waves. We can also easily see, considering the Balearic Promontory South to Minorca, that there is a clear influence on the waves amplitudes of a submarine canyon (Minorca Canyon system described by Acosta et al., 2002) (Fig. 7): in fact, in front of the canyon, the amplification is very low while it is important on both sides of the canyon. This is mostly due to the shoaling effect which slows down and amplifies the waves around the canyon, and is rather different from results obtained in a yet similar configuration off Myanmar during the 2004 Indian Ocean tsunami (Ioualalen et al., 2007). A similar phenomenon is observed offshore the Cap Blanc and offshore the coastline between Porto Cristo and Cala Rajada in Majorca (Figs. 4A and B).

\section{Conclusions}

The evaluation of the Djijelli 1856 earthquake macroseismic intensity is biased due to the offshore location of the main shock. The seismogenic potential and the faults system geometry offshore Djijelli is poorly documented, and events of such magnitude in the area are very rare. The lack of historical data of tsunami observations in the Balearic Islands in 1856 do not allow us to completely compare and validate our results based on tsunami modellings and thus our new source hypothesis. But we can mention here that the wave arrivals in the Balearic Islands concerning the 2003 tsunami are reported with highest values/damage in the same areas (except Ibiza) than for the modelled 1856 results, highlighting the highest exposure of the southeastern coast of Majorca to tsunamis coming from central and eastern Algeria.

On another hand, could the waves reported in Mahon be related to any submarine landslide? Indeed, submarine landslides can occur along the Algerian coast (Dan et al., in press; Domzig et al., submitted), mostly due to the very steep slopes of the area. Some of them can occur after seismic shaking (such as turbidites after the 1980 and 2003 earthquakes). The so-generated waves could reach levels consistent with the observations reported in Algeria. But these waves possibly generated by such landslides are probably not able to reach the Balearic Islands area: the shorter waves involved are unable to propagate at long distances without a significant dispersion that reduces the wave heights. Thus the reported flooding and destruction in Mahon could be explained by this kind of waves only if they are generated in short field (slopes of the Balearic Promontory).

Another possible interpretation could be the fact that there was a storm in Western Mediterranean at this time which could have led to destruction in Mahon harbour due to sea level rise correlate with atmospheric depression move. Thus the reports of floodings/destructions along the Algerian coast could be due to a local tsunami generated by a submarine landslide.

A perspective to this study would be to increase the resolution of our grids in test sites as Mahon and Palma and probably to choose other test sites more inclined to wave amplification on the East coast of Majorca and/or on the South coast of Minorca, in accordance with the actual inhabited areas, particularly those which present special reactions to rissaga phenomenon in order to calculate run-up. Then additional sources should be tested with various locations and strikes in order to constrain more precisely the hazardous areas in the Balearic, maybe with a systematic approach (Roger and Hébert, 2008). Finally, an on-field study concerning the possibility of existence of tsunami deposits in Western Mediterranean has to be taken into account with a special focus onto the Balearic Islands, in order to identify paleotsunamis, distinguishing them from storm events and propose recurrence period.

Acknowledgements. This work was performed within the framework of and funded by the European project TRANSFER under the contract 037058. We thank A. Domzig and J. Déverchère for their supply of information concerning the geodynamical interpretation of the Algerian offshore margin. Seismicity plotted on Fig. 1 was provided by EMSC-CSEM (www.emsc-csem.org). We are indebted to two anonymous reviewers and to A. B. Rabinovich who gave precious advices to improve the paper. Remarks made by F. Schindelé were also taken into account, and we acknowledge support from CEA.

Edited by: S. Tinti

Reviewed by: A. Rabinovich and two other anonymous referees

\section{References}

Acosta, J., Canals, M., Lopez-Martinez, J., Munoz, A., Herranz, P., Urgeles, R., Palomo, C., and Casamor, J. L.: The Balearic Promontory geomorphology (western Mediterranean): morphostructure and active processes, Geomorphology, 49, 177204, 2002.

Adams, R. D. and Barazangi, M.: Seismotectonics and seismology in the Arab region: a brief summary and future plans, Bull. Seism. Soc. Am., 74(3), 1011-1030, 1984.

Aki, K.: Generation and propagation of G-waves from the Niigata earthquake of 16 June 1964 - 2. Estimation of earthquake movement, released energy and stress-strain drop from G spectrum, Bull. Earthq. Res. Inst., 44, 23-88, 1966.

Alasset, P. J., Hébert, H., Maouche, S., Calbini, V., and Meghraoui, M.: The tsunami induced by the 2003 Zemmouri earthquake 
$(\mathrm{Mw}=6.9$, Algeria $)$ : modelling and results, Geophys. J. Int., 166, 213-226, 2006.

Ambraseys, N. N.: The seismicity of North Africa: the earthquake of 1856 at Jijeli. Bollettino Di Geofisica a Teorica ed Applicata. Vol. XXIV, No.93, 31-37, 1982.

Antonopoulos, J.: Data for investigating tsunami activity in the Mediterranean sea, Science of Tsunami Hazards, 8(1), 39-52, 1990.

Aoudia, A., Vaccari, F., Suhadolc, P., and Meghraoui, M.: Seismogenic potential and earthquake hazard assessment in the Tell Atlas of Algeria. Journal of Seismology, 4, 79-98, 2000.

Aucapitaine, M.: Note sur le tremblement de terre ressenti en Algérie du 21 au 25 août 1856. C. R. Acad. Sc. Paris, 2ème semestre, T. XLIII, 16, p. 765, 1856.

Ayadi, A., Maouche, S., Harbi, A., et al.: Strong Algerian earthquake strikes near capital city, EOS, 84(50), 5068, 561 pp. , 2003.

Bellotti, G.: Transient response of harboursto long waves under resonance conditions, Coast. Eng., 54, 680-693, 2007.

Bezzeghoud, M., Dimitrov, D., Ruegg, J. C., and Lammali, K.: Faulting mechanism of the El Asnamn (Algeria) 1954 and 1980 earthquakes from modelling of vertical movements, Tectonophysics, 249, 249-266, 1995.

Bilek, S. L. and Lay, T.: Rigidity variations with depth along interpolate megathrust faults in subduction zones, Nature, 400, 443446, 1999.

Braunmiller, J. and Bernardi, F.: The 2003 Boumerdes Algeria earthquake: regional moment tensor analysis, Geophys. Res. Lett., 32, L06305, doi:10.1029/2004GL022038, 2005.

British Oceanographic Data Centre - The Centenary Edition of the GEBCO Digital Atlas, http://www.gebco.net/data_and_products/ gebco_digital_atlas/, Liverpool, UK, 1997.

Calais, E., DeMets, C., and Nocquet, J.-M.: Evidence for a post3.16 Ma change in Nubia-Eurasia plate motion, Earth Planet. Sci. Lett., 216, 81-92, 2003.

Dan, G., Savoye, B., Cattaneo, A., Gaullier, V., Déverchère, J., Yelles, K., and Maradja 2003 team: Recent sedimentary patterns on the Algerian margin (Algiers area, southwestern Mediterranean), AAPG/SEPM (Society for Sedimentary Geology) Special Vol. 93, Geological Society of America, in press, 2008.

Delouis, B., Vallée, M., Meghraoui, M., Calais, E., Maouche, S., Lammali, K., Mahsas, A., Briole, P., Benhamouda, F., and Yelles, K.: Slip distribution of the 2003 BoumerdesZemmouri earthquake, Algeria, from teleseismic, GPS, and coastal uplift data, Geophys. Res. Lett., 31, L18607, doi:10.1029/2004GL020687, 2004.

Deschamps, A., Gaudemer, Y., and Cisternas, A.: The El Asnam, Algeria, earthquake of 10 October 1980: multiple-source mechanism determined from long-period records. Bull. of the Seism. Soc. of Am., 72(4), 1111-1128, 1982.

Domzig, A.: Déformation active et récente, et structuration tectonosédimentaire de la marge sous-marine algérienne. Thèse de Doctorat de l'Université de Bretagne Occidentale, 332 p., 2006.

Domzig A., Yelles K., Le Roy C., Déverchère, J., Bouillin, J-P., Bracène, R., Mercier De Lépinay, B., Le Roy, P., Calais, E., Kherroubi, A., Gaullier, V., Savoye, B., and Pauc, H.: Searching for the Africa-Eurasia Miocene boundary offshore western Algeria (MARADJA'03 cruise). C. R., Géoscience, 338, 80-91, doi:10.1016/j.crte.2005.11.009, 2006

Domzig, A., Gaullier, V., Giresse, P., Pauc, H., Déverchère, J., and Yelles, K.: Deposition processes from echo-character mapping along the western Algerian margin (Oran-Tenes), Western Mediterranean, submitted, Marine and Petroleum Geology, special volume on Slope Instabilities, in press, 2008.

Gaultier de Claubry, M.: Sur les effets du tremblement de terre du 21 et 22 août 1856 dans certaines parties de l'Algérie, C. R. Acad. Sc. Paris, T. XLIII, 589-590, 1856.

Geist, E. L. and Bilek, S. L.: Effect of depth-dependent shear modulus on tsunami generation along subduction zones, Geophys. Res. Lett., 28(7), 1315-1318, 2001.

Gomis, D., Monserrat, S., and Tintoré, J.: Pressure-forced seiches of large amplitude in inlets of the Balearic islands, J. Geophys. Res., 98(C8), 14 437-14 445, 1993.

Harbi, A.: Analyse de la sismicité et mise en évidence d'accidents actifs dans le nord-est algérien, Thèse de Magister, 196 pp. USTBH Alger, 2001.

Harbi, A., Benouar, D., and Benhallou, H.: Re-appraisal of seismicity and seismotectonics in the north-eastern Algeria. Part I: Review of historical seismicity, J. Seismol., 7, 115-136, 2003.

Harbi, A., Benouar, D., and Benhallou, H.: Re-appraisal of seismicity and seismotectonics in the north-eastern Algeria. Part I: Review of historical seismicity, J. Seismol., 7, 115-136, 2003.

Harbi, A., Maouche, S., and Ayadi, A.: Neotectonics and associate seismicity in the Eastern Tellian Atlas of Algeria, J. Seismol., 3, 95-104, 1999.

Hébert, H., Heinrich P., Schindelé F., and Piatanesi A.: Far-field simulation of tsunami propagation in the Pacific Ocean: impact on the Marquesas Islands (French Polynesia), J. Geophys. Res. 106, 9161-9177, 2001.

Hébert, H., Roger, J., and Schindelé, F.: Advances in tsunami hazard assessment in the western Mediterranean Sea, Geophys. Res. Abstracts, 9, 06341, SRef-ID: 1670-7962/gra/EGU2007-A06341, EGU Vienna, 2007a.

Hébert, H., Sladen, A., and Schindelé, F.: The great 2004 Indian Ocean tsunami: numerical modeling of the impact in the Mascarene Islands, B. Seismol. Soc. Am., 97, 1A, 208-222, 2007b.

Ioualalen, M., Pelinovsky, E., Asavanant, J., Lipikorn, R., and Deschamps, A.: On the weak impact of the 26 December Indian ocean tsunami on the Bangladesh coast, Nat. Hazard. Earth Syst. Sci., 7, 141-147, 2007.

Jansa, A., Monserrat, S., and Gomis, D.: The rissaga of 15 June 2006 in Ciutadella (Menorca), a meteorological tsunami, Adv. Geosci., 12, 1-4, 2007, http://www.adv-geosci.net/12/1/2007/.

Liu, P. L.-F., Monserrat, S., Marcos, M., and Rabinovich, A. B.: Coupling between two inlets: Observations and modelling, J. Geophys. Res., 108(C3), 3069, doi:10.1029/2002JC001478, 2003.

Maramai A., Graziani L., and Tinti S.: Updating and revision of the European Tsunami Catalogue, NATO Sciences Series: Submarine Landslides and Tsunamis, edited by: Yalciner, A. C., Pelinovsky, E., Okal, E., and Synolakis, C., Kluwer Academic Publishers, 25-32, 2003.

Meghraoui, M., Alasset, P.-J., and Hébert, H.: Potential tsunamigenic earthquake sources along the Algerian coast: lessons learned from recent earthquakes and implications for the western Mediterranean Sea, Geophys. Res. Abstracts, 8, 10009, SRef-ID: 1607-7962/gra/EGU06-A-10009, 2006.

Meghraoui, M., Maouche, S., Chemaa, B., Cakir, Z., Aoudia, A., 
Harbi, A., Alasset, P.-J., Ayadi, A., Bouhadad, Y., and Benhamouda, F.: Coastal uplift and thrust faulting associated with the $\mathrm{Mw}=6.8$ Zemmouri (Algeria) earthquake of 21 May 2003, Geophys. Res. Lett., 31, L19605, doi:10.1029/2004GL020466, 2004.

Meghraoui, M., Philip, H., Albarede, F., and Cisternas, A.: Trench investigations through the trace of the $1980 \mathrm{El}$ Asnam thrust fault : evidence for paleoseismicity. B. Seism. Soc. Am., 78(2), 979-999, 1988

Mokrane, A., Ait Messaoud, A., Sebai, A., Ayadi, A., Bezzeghoud, M., and Benhallou, H.: Les séismes en Algérie de 1365 à 1992, Publication du Centre de Recherche en Astronomie, Astrophysique et Géophysique, Département Etudes et Surveillance Sismique, ESS, C. R. A. A. G., Alger-Bouzaréah, 277 pp., 1994.

Monserrat, S., Ibbetson, A., and Thorpe, A. J.: Atmospheric gravity waves and the 'Rissaga' phenomenon, Q. J. R., Meteorol. Soc., 117, 553-570, 1991.

Monserrat, S., Vilibic, I., and Rabinovich, A. B.: Meteotsunamis: atmospherically induced destructive ocean waves in the tsunami frequency band, Nat. Hazard. Earth Sys. Sci., 6, 1035-1051, 2006.

Morita, S. and Nakamura, T.: A optimum design of wave resonators for coastal and harbour structures, Proceedings of Japan Society of Civil Engineers (JSCE), 740, 143-155, 2003.

Nakamura, T., Morita, S., and Takemoto, T.: Effectiveness of a large resonator installed at the harbour entrance for mitigating long-period wave, Memoirs of the Faculty of Engineering, Ehime Univ., 19, 269-277, 2000

Nocquet, J.-M. and Calais, E.: Crustal velocity field of western Europe from permanent GPS array solutions, 1996-2001, Geophys. J. Int., 154, 72-88, 2003.

Nocquet, J.-M. and Calais, E.: Geodetic measurements of crustal deformation in the western Mediterranean and Europe, Pure Appl. Geophys., 161, 000-0000033-4553/04/000000-00, doi:10.1007/s00024-003-2468-z, 2004.

Okada, Y.: Surface deformation due to shear and tensile faults in a half-space, Bull. Seismol. Soc. Am., 75, 1135-1154, 1985.

Okal, E.: Seismic parameters controlling far-field tsunami amplitudes: a review, Nat. Hazard. Earth Sys. Sci., 1, 67-96, 1988.

Papadopoulos, G. A. and Fokaefs, A.: Strong tsunamis in the Mediterranean Sea: a re-evaluation, ISET Journal of Earthquake Technology, 463(42 \#4), 159-170, 2005.

Peláez Montilla, J. A., Hamdache, M., and López Casado, C.: Seismic hazard in northern Algeria using spatially smoothed sesismicity. Results for peak ground acceleration, Tectonophysics, 372, 105-119, 2003.

Rabinovitch, A. B. and Monserrat, S.: Meteorological tsunamis near the Balearic and Kuril Islands: descriptive and statistical analysis, Nat. Hazard. Earth Sys. Sci., 13, 55-90, 1996.

Rabinovich, A. B. and Monserrat, S.: Generation of Meteorological Tsunamis (Large Amplitude Seiches) Near the Balearic and Kuril Islands, Nat. Hazard. Earth Sys. Sci., 18, 27-55, 1998.

Roger, J. and Hébert, H.: Tsunami hazard in Western Mediterranean: preliminary study of scenarios for the Balearic, Eos Trans. AGU, 88(52), Fall Meet. Suppl., Abstract S53A-1009, 2007.
Roger, J. and Hébert, H.: Systematic approach of tsunami modelling in Western Mediterranean, Geophys. Res. Abstracts, 10, EGU2008-A-02141, 2008.

Rothé, J.-P.: Les séismes de Kerrata et la sismicité de l'Algérie, Bulletin du service de la carte géologique de l'Algérie, 4ème série, Géophysique, 3, 40 pp., 1950.

Ruegg, J. C., Kasser, M., Tarantola, A., Lepine, J. C., and Chouikrat, B.: Deformations associated with the El Asnam earthquake of 10 October 1980: geodetic determination of vertical and horizontal movements, Bull. Seism. Soc. Am., 72(6), 22272244, 1982.

Semmane, F., Campillo, M., and Cotton, F.: Fault location and source process of the Boumerdes, Algeria, earthquake inferred from geodetic and strong motion data, Geophys. Res. Lett., 32, L01305, doi:10.1029/2004GL021268, 2005.

Senarmont (De), M. H.: Analyse des documents recueillis sur les tremblements de terre ressentis en Afrique du 21 août au 15 octobre 1856, C. R. Acad. Sc., Paris, T. XLIV, 586-594, 1856.

Serpelloni, E., Vannucci, G., Pondrelli, S., Argnani, A., Casula, G., Anzidei, M., Baldi, P., and Gasperini, P.: Kinematics of the western Africa-Eurasia plate boundary from focal mechanisms and GPS data, Geophys. J. Int., 169, 1180-1200, 2007.

Seutter, M.: Carte des illes de Maiorque, Minorque et d'Yvice gravée par Matthieu Seutter, Graveur de S.M. Imper. et Cathol., Augsbourg, 1741.

Soloviev, S. L., Solovieva, O. N., Go, Ch. N., Kim, Kh. S., and Shchetnikov, N. A.: Tsunamis in the Mediterranean Sea, 2000 B.C.-2000 A.D., Advances in Natural and Technological Hazards Research, Kluwer Academic Publishers, 260 p., 2000.

Stock, C. and Smith, E. G. C.: Evidence for different scaling of earthquake source parameters for large earthquakes depending on faulting mechanism, Geophys. J. Int., 143, 157-162, 2000.

Tinti, S., Maramai, A., and Graziani, L.: A new version of the European tsunami catalogue: updating and revision, Nat. Hazard. Earth Sys. Sci., 1, 255-262, 2001.

Wells, D. L. and Coppersmith, K. J.: New empirical relationships among magnitude, rupture length, rupture width, rupture area, and surface displacement, B. Seismol. Soc. Am., 84(4), 974 1002, 1994.

Yelles-Chaouche, A. K.: Coastal Algerian Earthquakes: a potential risk of tsunamis in western Mediterranean? Preliminary investigation, Science of Tsunami Hazards, 9(1), special issue, 47-54, 1991.

Yelles-Chaouche, A. K., Déverchère, J., Domzig, A., Mercier de Lepinay, B., Babonneau, N., Hébert, H., Roger, J., Kherroubi, A. Graindorge, D., Bracene, R., Cattaneo, A., Gaullier, V., Savoye, B., Leroy, P., and Ait Ouali, R.: The tsunami of Djijelli (Eastern Algeria) of 21-22nd August 1856: the seismotectonic context an dits modelling, XXIV Assembly of IUGG, Perugia, Italy, JSS002, 2007.

Yelles, A. K., Lammali, K., Mahsas, A., Calais, E., and Briole, P.: Coseismic deformation of the 21st May 2003, $\mathrm{Mw}=6.8$ Boumerdes earthquake, Algeria, from GPS measurements, Geophys. Res. Lett., 31, L13610, doi:10.1029/2004GL019884, 2004. 